DMITRY MOSYAKOV, UNSIYA OMAROVA. THE "NEW ISLAMIZATION OF CHAMS" CAUSES AND CONSEQUENCES FOR CAMBODIA* // The article was written for the bulletin "Russia and the Moslem World."

Keywords: Islam, the Cham, Muslim preachers, International Islamic Foundations, Cambodia.

\title{
Dmitry Mosyakov,
}

DSc(History), Professor,

Director of the Center for Southeast Asia,

Australia and Oceania

Unsiya Omarova,

$\mathrm{PhD}$ (History),

Ministry of Foreign Affairs of the Republic of Kazakhstan

Citation: Mosyakov D., Omarova U. The "New Islamization of Chams" Causes and Consequences for Cambodia // Russia and the Moslem World, 2020, No. 3 (309), P. 94-105. DOI: $10.31249 / \mathrm{rmw} / 2020.03 .08$

Abstract. The article is devoted to the current state of the Cham Islamic community in Cambodia. The authors analyze how the ideas of radical Islam, which is distributed among Cambodian Cham, with the direct participation and support of Islamic international foundations, affect the state of the Islamic community, what threats and challenges it faces.

The Cham people are one of the oldest ethnic groups in Southeast Asia, who built one of the most powerful states in the region throughout antiquity and the Middle Ages - Champa (or Tsiompa). They professed Hinduism, later converted to traditional Islam. A significant part of the population moved to Cambodia after the defeat of the Cham state by the Vietnamese in the 15th century, and integrated into Cambodian society. The

\footnotetext{
* Translation of the title is presented in author's version.
} 
Cham people were subjected to mass persecution under the Pol Pot regime, they were forbidden to practice Islam. Significant changes began to occur in the Cham society in 1979 - after the defeat of the Khmer Rouge regime and especially after the cessation of the war and general elections in Cambodia under the control of the UN in 1993. Some Cham intellectuals consider them a "spiritual rebirth", for example, the Cham historian and philosopher Po Dharma (Quảng Văn Đủ), who lives in Paris.

Is there really such a "spiritual rebirth"? Can one suppose its manifestation in the spread of radical Islamic ideas combined with the loss of the traditional Cham identity both in the way of life and in the sphere of self-consciousness of the Cham ethnic group? The authors conducted a thorough analysis of the processes that have covered the Cham community in Cambodia since 1993 (there are different estimates from 250 thousand to 800 thousand people) to answer this question. The Cham community in Cambodia came into the spotlight when dozens of radical Islamic preachers, acting on behalf of global Islamic foundations, appeared in Cambodia after the end of the civil war in 1993. Formally, their arrival was related to the appeal from many authoritative and respected people in the Cham community to all Muslim countries and associations to provide financial assistance for the restoration of the Muslim community of Cambodia, which, they said, was dying after the war and ten years of Vietnamese occupation. Salafists, followed by several more international Islamic non-governmental organizations (NGOs) from Arab countries and Malaysia, arrived in the country in response to this call.

In a short time, almost the entire Cham society from imams of mosques and local authorities to ordinary people came under very strong ideological influence, since most foreign missionaries believed that the Cham in Cambodia do not follow Islam well and, therefore, urgently need to "purify their faith". Each of the arriving preachers saw that "purification" in their own way and made efforts so that the theology of him and his like-minded 
people would be accepted by the Cham. This imperative led to rivalry between missionaries and conflicts in the Cham communities, when two or three different groups of preachers competed for followers in the same place (for example, in the villages of Chumnik and Soi in Kampong Cham province).

That missionaries convinced the Cham that their traditional Islamic practice was not very "pure," especially visiting the mosque once a week on Fridays, and now they needed to adopt new practices in order to purify their faith. People were convinced that their traditionally professed Islam was "wrong Islam," and these missionaries from the Arab East, Pakistan or Malaysia, carried true and correct Islam, showing how to live and pray.

Their arguments were all the more convincing as their financial foundations and organizations helped believers financially - they distributed food, necessary goods, paid a hajj to Mecca for the most authoritative people, and, what was even more important, their emissaries selected and sent young people to Islamic religious centers abroad for a greater perception of "new Islam." This simple propaganda, based on relatively small financial investments (taking into account the actual budgets of global Islamic charitable funds), proved to be quite effective - at least, it was enough to change the religious guidelines of a significant part of the Cham society.

The enormous interest of the Cham majority in the "new Islam" became noticeable already in the mid-1990s, in contrast to some other places in the Islamic world, where the Salafis did not succeed much with their propaganda and where the faithful adhered to their traditional spiritual heritage and knowledge led by their religious leaders - muftis, imams of mosques and authoritative Muslims. It is difficult to explain what prompted the Cham majority to a rather radical departure from their traditional Islam. Perhaps the desire for change was caused by the consequences of the genocide during the period of the Pol Pot regime, their certain isolation, and the control of the authorities 
during the period of People's Kampuchea. They expected to change their position in Cambodia through active cooperation with Islamic international foundations and with their help and support to become part of the vast world of Islam, and not feel like just a small people surrounded by the Khmer majority.

Also, one cannot ignore the material factor. The Cham communities continued to live very hard and very poor, despite all the positive changes, except that the threat of hunger, still relevant in the early 1980s, had almost disappeared by then. Therefore, any donations from foreign co-religionists were perceived extremely positively, and the Salafis always had money, and most importantly the ability to manage them. It can be said that a whole range of factors predetermined the religious reorientation of the majority from traditional to radical Islam brought by Salafists from Arab countries and Pakistan.

As for the Cambodian authorities, they preferred either not to notice the changes taking place in the Cham environment for a long time, or even indulged them, apparently believing that the donates of the Arab countries, Pakistan and Malaysia contribute to maintaining calm among the Cambodian Muslims and increasing their living standards. The authorities did not take into account the facts that Islamic funds were active in the country, such as the Saudi Om-al-Qura, La Wamy (World Assembly of Muslim Youth), L'IIRO (International Islamic Relief Organization) and a number of others from Kuwait and Pakistan, blacklisted by the U.S. Department of State, as they were seen funding the training of Islamic militant terrorists. ${ }^{1}$

More important for the government was the stability of the situation in the settlements, and the support given to Hong Sen and his party by both the Cham people and their leaders in full. Therefore, the authorities often made serious concessions to the radical preachers. They were allotted territories and allowed to build new mosques, open religious schools, and create foundations subordinate to themselves already in Cambodia, and in 2008 the government even decided to allow all Muslim 
students and government employees to wear Islamic clothes in classrooms and workplaces. ${ }^{2}$

In turn, the Cham showed their loyalty to Prime Minister Hong Sen, the long-term ruler of Cambodia, especially during the events of 1998, when he defeated the opposition at once. One of the strike forces was just units with a predominance of Cham soldiers during short-lived battles in Phnom Penh. The Hun Sen government supported the Cham people in response, for example, each family was given 3 hectares of land in the area of Sihanoukville for free.

It is also clear that the Khmer ruling elite, who worked closely with the Cham top community, was not fully aware of the essence of the processes taking place among the Cham, especially since they were not noticeable at first. They considered Salafists and donates coming from Muslim states as another source of funds for rebuilding the country than as actions that threaten Cambodia's national unity and integrity in the near future.

In the early 2000s, changes in the Cham community became visible to the naked eye. In conservative Cambodia, girls in Arabic clothes appeared who tried to learn Arabic instead of the Khmer language. They behaved in many ways defiantly, did not look like ordinary Cham women, and claimed that their cultural identity was not Cambodia, its history and culture, and not even Champa, but the world of Islam. They began to declare everywhere that Cham were taller and stronger than Khmers in all respects, demonstratively indicating that they did not represent the traditional Khmer-Cham, but a much more powerful and influential Islamic world in Cambodia. In many villages, except for some that remained traditionalist, the national Cambodian scarf - krama - on the heads of Cham women was replaced by a hijab or tudung (Malaysia' veil, covering the hair) ${ }^{3}$.

In some areas, very young girls began to wear a black burqa (purdah) covering their face, although L. Robet, a wellknown researcher of Cham life and culture, noted in the late 1990s that Cham women did not wear an Islamic veil ${ }^{4}$. The same 
author pointed out a little later that wearing a hijab among Cham women was never as widespread as at that time, which confirmed the extremely rapid evolution of Muslim society in Cambodia.

Muslim clothing has become something quite common for Cham women today. They follow rather Malaysians, where almost the vast majority of women wear Islamic clothing at all times, and if not the hijab, then at least the headscarf. So in contrast to the early 2000s, today this is no longer surprising, but rather a variant of the norm.

Not only women were affected by external changes, a similar trend occurred in men. According to the observations of the French journalist Agnes De Feo, who studied the Cham people, they began to wear plaid headscarves and juba gowns, just like their Arab preachers. Many began to wear a beard, which was extremely rare earlier among the Cham. The Cham themselves argue that all the external changes in their appearance are not just a change of clothes, they consider this a national revival, the formation of their own new Islamic identity, and clearly contrast themselves with Khmers. ${ }^{5}$

Their new Salafi teachers are constantly campaigning for such changes in the appearance of men and women, convincing them that demonstratively following Islamic customs serves to verify the truth of the Muslim faith. A faithful Muslim, as they teach the Cham, should stand out among others not only by his behavior, but also by his active testimony of his faith - Friday prayer in a mosque, circumcision ceremony, sacrifice of a ram, performing a hajj, wearing a hijab for women, giving up meals, if the food is not halal, etc.

Naturally, the transformational process of such magnitude and profound changes that captured the Cham world could not but be accompanied by certain conflicts that arose naturally between the "old" and "new" Muslims. The "old" are older people, mostly survivors of the era of the Pol Pot genocide, who did not approve of all these innovations; they were frightened 
that the Cham began to oppose themselves to the Khmer majority more and more, emphasizing their differences and superiority. There was a kind of conflict situation between generations, when "children" who were trained by radicals began to reproach their "parents" for religious errors, and called them to change.

Today, it is the youth of the Cham who are pushing their parents to move to a virtually new religion for them with more or less success. This is the plan for reformatting the religious preferences of Cham society. Therefore, various kinds of religious associations, which have occupied the sphere of education and religion, rely on the teaching of Islam primarily among children. They organize orphanages not only for homeless or abandoned children, but also for those who live in normal conditions in families and do this in order to increase the effectiveness of their preaching. By the way, the Salafis operate approximately according to the same plan in Cambodia, as in all Muslim countries - religious education begins with the education of children. Nowadays, this practice is very widespread among the Cham and is already supported not only by the external foundations of the Islamic world, but also by the Cambodian government. According to Saleh Abutalib, an Islamic businessman who helps a lot with religious education, a madrasah was created at the "8-kilometer" mosque with the support of one of the Arab foundations, where 700 students study in two shifts today. They are trained by 25 teachers, and if previously they were paid partly by the parents of students, partly by foreign, primarily Arab funds, now they are paid by the state at the suggestion of Hun Sen. At the same time, 13 teachers out of 25 receive one million riels each (\$250), which is quite a lot by Cambodian standards. According to Saleh Abutalib, there were only 150 mosques in Cambodia before Pol Pot, now there are more than $1000^{6}$. As for the education of Cham children, some Cham schools even switch from Cham to Arabic in the learning process according to the testimony of Farina So, another informant. The reason is that Arabic speakers find work easily. 
The government pays well for teaching Arabic. 1,500 Cham teach Arabic and religion today 7 . The transition to Arabic as the main foreign language, and the shift of Khmer - the state language - to the third place testifies eloquently to the depth of the changes taking place among the Cham.

Probably, for a more adequate idea of what is happening in the Cham society and the degree of its radicalization, the Cham began to receive some help, even from the United States. In particular, funds were allocated for teaching English and sewing, and the Americans financed such NGOs as the Cambodian Muslim Community, the Cambodian Islamic Youth Association, the Islamic Local Development Organization, and the Imam San Association, which had already been created by the Chams themselves.

There is no doubt that international Islamic foundations and structures, with their headquarters in the Persian Gulf and Pakistan, are the main donors paying the cost of changing the religious direction. There are several dozens of nongovernmental organizations (NGOs) that conduct a scholarship program for the money received from Islamic funds, allowing students to study at home and abroad. Most go to study in Malaysia and Indonesia. It is difficult to immediately list the entire set of NGOs engaged in retraining and propaganda of "the right Islam", which have the opportunity to send the most successful students abroad to the Arab East, Pakistan and Malaysia, to pay the Hajj for imams and authoritative and most influential parishioners. Among the largest and most famous structures are: "Cambodian Islamic Youth", "Cambodian Muslim Student Association", "Cambodian Muslim Development Fund", "Cambodian Charity Association", "Cambodian Muslim Alliance" and "World Muslim Youth Assembly". Some Arab NGOs do not operate through local intermediaries, but directly through their offices in Cambodia. Representatives of "Partners for Development" NGO arrived from Kuwait in 1996 and opened an Islamic high school under their patronage. Later, the same 
NGO established its branches in various provinces, where especially many Muslims live. In 2007, another Kuwaiti organization, "Society for Social Reform - State of Kuwait", came to Cambodia and began to actively engage in charitable activities, a scholarship program, and community social development.

"Revival of Islamic Heritage Society" (RIHS), another organization from Kuwait, is located in the capital of Cambodia. This organization took on the training of several hundred Cham orphans. Moreover, it is known that radical Wahhabis Islam is promoted and taught there. The Cambodian government did not take any action to restrict the activities of Kuwaiti missionaries, as well as emissaries of other Islamic countries, up to Nigeria, which operate with the support of the Kuwait Fund. Moreover, the government noted that Kuwaiti investments were highly appreciated and it was undesirable to lose them. In this regard, Kuwaitis were allowed to open five more such boarding schools for orphans in the provinces 8 .

This activity of numerous foundations and related structures and preachers leads to their competition with each other for influence on the Cham; this competition affects society, and as a result, not only different generations do not understand each other, but representatives of the same generation are largely opposed to each other. Some (chwea) began to call other (jat) pejoratively as fasik, i.e. sinner, or sindir, if this person expressed doubt about the "five pillars of Islam." The worst thing happened when some Cham began to call their fellow tribesmen as murtad (i.e. apostate) if they do not want to follow their path'.

There are a number of other examples showing that there are deep changes in the Cham society life, changing their traditional customs and habits. There are a number of other examples that show that there are deep changes in the life of the Cham society, changing their traditional customs and habits. Earlier, the cult of saints was widespread among them, as evidenced by Etienne Aymonier, one of the founders of the French school for the study of the Far East, who noted that the 
Cham of Cambodia venerate the tombs of the righteous, surrounded by a halo of Holiness. When they visit these rather numerous tombs, they stop, bow down and pray ${ }^{10}$. In Cambodia, these tombs are found everywhere in the Cham habitat. In this regard, A. Kabaton did not hide his surprise at the prevalence of so many tombs of Muslim saints in the Khmer land ${ }^{11}$. However, the cult of saints, widespread in the Muslim world, is condemned by modern Salafists, as is known.

And so, the traditional Muslim order does not just go by the wayside, it becomes less generally accepted in a relatively short time, but even practically disappears along with the graves of the Cham sheikhs, which are either destroyed or abandoned and cease to be a place of worship. For example, the grave of Po Sei Bray in the village of Rokapo Pram once served as an object of special worship. They made sacrifices and preserved the tradition of the origin of the Cham and their loss of land, since it was there that the Cham ruler was buried, having suffered a decisive defeat from the Vietnamese army. Earlier in this village, you could always meet many Cham pilgrims who arrived from all over Cambodia ${ }^{12}$. Today, there is a certain desolation there, as well as next to the tombs of other historical figures, spiritual and religious leaders and teachers that have been destroyed and disappeared. Memorials that have been the object of worship in many places earlier, nowadays are either in an abandoned state or simply disappeared, and their disappearance did not cause much protest in the Cham society and the desire to restore them.

It is hard to believe that only the tomb of the famous Imam San (an associate of King Ang Duong) is revered even today, thanks to conservatism or even direct resistance from a relatively small part of the Cham society, not obsessed with radical views. This small group is called Cham-Jat and has recently become more and more isolated from the rest of the Cham world ${ }^{13}$.

It is hardly correct to call the changes in the Cham society as "spiritual revival." 
Firstly, if the Cham never had radical Islam in their long history, then what kind of revival could it be? Secondly, the radical rejection of the traditional way of life and traditional Islam embedded in the daily lives of people causes an increasingly clear internal split of the Cham society and religious community, when some follow missionaries from the Middle East, others follow Pakistani radicals; when there is not only a cultural conflict of generations, but also a conflict within communities, when clashes occur where they have never been. And thirdly, the radicalization of the Cham forms a barrier between them and the Khmer majority destroys their historical integration into Cambodian life. The Khmer look at the arabized Cham with suspicion and the possibilities of social elevators for the Cham are rapidly diminishing. Reports that some young Cham went to war in Syria or even neighboring Thailand do not represent the Cham community in a positive light either.

So the question remains open so far: will authoritative religious and public figures be able to stop the process of radicalization and find a balance between radical and traditional Islam and to what extent? Only the future will show whether the Cham can maintain their unity, culture and lifestyle, or whether they will be divided into warring Muslim groups and turn into people without any roots.

\section{Reference}

1. De Feo, A. Les Chames, l'Islam, la revendication identitaires, Paris, Mémoire de DEA, EPHE, Section IV, 2004. P. 91.

2. Interview with Muhammad bin Hassan, Imam of Al-Serkal Mosque. March $18,2018$.

3. Metzger, L. Strategie islamique en Malaisie (1975-1995). P.: L'Harmattan, 1996; Phnom Penh Post. "Cham Muslims in Cambodia», Issue 10/22, October 26 November 8, 2001.

4. Robet, L. De l'intégration des Cham au Cambodge, mémoire de l'Institut d'études politiques d'Aix-Marseille III, dirigé par Guy Drouot, 1997, P. 20.

5. (De Feo p. 86)

6. Interview with Solekhbin Abutalip, a businessman - a representative of one of the NGOs, March 18, 2018. 